\title{
GLOSY
}

\author{
JĘDRZEJ MaŚNICKI
}

Uniwersytet Warszawski

\section{GODNOŚĆ CZŁOWIEKA W ŚWIETLE ORZECZENIA OLIVER BRÜSTLE PRZECIWKO GREENPEACE EV \\ $(\mathrm{C}-34 / 10)^{1}$}

Odpowiadając na pytanie dotyczące wpływu rozwoju nauki na współczesne prawo, nie sposób pominąć sprzężenia dynamicznie rozwijającej się biomedycyny oraz uregulowań ponadnarodowych ${ }^{2}$. Dotychczasowy rozwój ustawodawstw państw członkowskich Unii Europejskiej pozostaje niejednolity i zróżnicowany. Jedne dążą do możliwie precyzyjnego prawnego dookreślenia kwestii rozwoju badań i przemysłowego wykorzystania komórek macierzystych i embrionów ludzkich, inne pozostawiają ten obszar jako prawną terra incognita, zawłaszczaną przez rozmaite grupy interesów ${ }^{3}$. Harmonizacja niektó-

1 Wyrok z dnia 18 października 2011 r. C-34/10 Oliver Brüstle przeciwko Greenpeace $\mathrm{eV}$., Zb.Orz., dotychczas nieopublikowany, dostępny na stronie: http://curia.europa.eu/ juris/liste.jsf?language= $=$ \&\&jur=C,T,F\&num=C-34/10\&td=ALL, dostęp 3 kwietnia $2013 \mathrm{r}$.

2 Szerszy przegląd współczesnych uregulowań międzynarodowych nie będzie przedmiotem niniejszego opracowania, został on już omówiony m.in. w: A. KRAJEWSKA, Badania naukowe na ludzkim materiale biologicznym [w:] Badania naukowe $z$ udziałem ludzi $w$ biomedycynie. Standardy międzynarodowe, red. J. RóżYŃSKA, M. Waligóra, Warszawa 2012.

3 Przegląd ustawodawstwa państw członkowskich zob. A. WNukiEwicz-KozŁowSKA, Zdolność patentowa embrionu ludzkiego $w$ kontekście orzeczenia Trybunału 
rych prawnych aspektów badań nad embrionami ludzkimi wydaje się być wskazana w świetle dalszego rozwoju technologicznego i utrzymania konkurencyjności państw członkowskich. Ponadto, rzadko który prawodawca krajowy byłby w stanie samodzielnie oprzeć się lobbingowi firm dążących do zapewnienia jak najlepszych warunków komercjalizacji efektów badań wątpliwych z etycznego punktu widzenia. Wyrazem tych dwóch dążeń jest Dyrektywa 98/44/WE Parlamentu Europejskiego i Rady z dnia 6 lipca 1998 r. w sprawie ochrony prawnej wynalazków biotechnologicznych, której motyw 7 stanowi: „Nieskoordynowany rozwój krajowych ustawodawstw dotyczących ochrony prawnej wynalazków biotechnologicznych we Wspólnocie, może prowadzić do dalszych utrudnień w handlu, szkód w rozwoju przemysłowym takich wynalazków oraz sprawnym funkcjonowaniu rynku wewnętrznego"4.

Rozwiązania przyjęte w dyrektywie o wynalazkach biotechnologicznych, częstokroć krytykowane jako niewystarczające dla osiągnięcia jej nadrzędnego celu, spotkały się ze znaczącym oporem na etapie implementacji do porządków wewnętrznych państw członkowskich ${ }^{5}$. Dowodem czego były liczne skargi Komisji o stwierdzenie uchybienia zobowiązaniom z art. 258 TFUE (art. 226 TWE) ${ }^{6}$. Rząd holenderski wniósł skargę do Europejskiego Trybunału Sprawiedliwości o stwierdzenie nieważności dyrektywy, podnosząc m.in. zarzut instrumenta-

Sprawiedliwości Unii Europejskiej z dnia 19 października 2011 r. w sprawie Brüstle przeciwko Greenpeace, «Przegląd Sejmowy» 4(111)/2012, s. 57-63 i literatura tam przywołana. Wartym uwagi pozostaje również przegląd orzecznictwa w sprawach o nadanie patentów dotyczących tkanek żywych, zob. E. BonAdio, Biotech patents and morality after Brustle, «European Intellectual Property Review» 2012, s. 436-439.

4 Dyrektywa 98/44/WE Parlamentu Europejskiego i Rady z dnia 6 lipca 1998 r. w sprawie ochrony prawnej wynalazków biotechnologicznych, Dz. Urz. WE $1998 \mathrm{Nr}$ L 213/13, dalej jako dyrektywa o wynalazkach biotechnologicznych.

5 W Polsce harmonizacja prawa krajowego do wymogów dyrektywy nastąpiła poprzez przepisy Ustawy z dnia 30 czerwca 2000 r. - Prawo wtasności przemysłowej ( Dz. U. z 2003 r. Nr 119, poz. 1117 z późn. zm.).

6 C-5/04 Komisja przeciwko Niemcom, C-4/04 Komisja przeciwko Austrii, C-456/03 Komisja przeciwko Włochom, C-454/03 Komisja przeciwko Belgii, C-450/03 Komisja przeciwko Luksemburgowi, C-448/03 Komisja przeciwko Francji. 
lizacji żywej materii ludzkiej i szkodliwości uregulowania wspólnotowego dla godności osoby ludzkiej, a ponadto, zagrożenia dla prawa osób do samostanowienia ${ }^{7}$. Wyrażone wówczas stanowisko Trybunału, iż: „dyrektywa ogranicza prawo do patentu w sposób wystarczająco rygorystyczny, aby zachowane były rzeczywiście nietykalność i nienaruszalność ciała ludzkiego, a tym samym, aby była zapewniona godność ludzka", wymagało jednak ponownego odczytania pod wpływem najnowszych osiągnięć technologicznych. Ponadto, podnoszono istnienie rozmaitych rozbieżności interpretacyjnych, które mogły prowadzić do wewnętrznej sprzeczności niektórych uregulowań dyrektywy dotyczących zakazu patentowania elementu wyizolowanego z ciała człowieka z zakazem patentowania ciała ludzkiego9.

Przyczynkiem do powtórnej analizy dyrektywy o wynalazkach biotechnologicznych stały się trzy pytania prejudycjalne skierowane przez federalny sąd krajowy (Bundesgerichtshof) zadane w związku z postępowaniem odwoławczym w sprawie o unieważnienie patentu nadanego dr. Oliverowi Brüstle ${ }^{10}$ wszczętym przez organizację Greenpeace. Przedmiotem patentu był sposób wytwarzania izolowanych i progenitorowych komórek nerwowych z embrionalnych komórek macierzystych. Metoda będąca przedmiotem spornego patentu miałaby zostać zastosowana do terapii wad układu nerwowego i pomóc w leczeniu takich schorzeń, jak choroba Parkinsona ${ }^{11}$. Wyizolowanie komórek macierzystych, które miałoby prowadzić do zniszczenia embrionów, wzbudziło wątpliwości co do zgodności patentu z art. 6 ust. 2 c) dyrektywy o wynalazkach biotechnologicznych, zgodnie

7 Wyrok z dnia 9 października 2001 r. C-377/98 Niderlandy przeciwko Parlamentowi i Radzie, Zb.Orz. 2001 I-07079, pkt 69.

8 Zob. pkt 77 wyroku TS w sprawie C-377/98.

9 H. ŻaKowska-Henzler, Wynalazek biotechnologiczny. Przedmiot patentu, Warszawa 2006, s. 319 i n.

${ }^{10}$ Oliver Brüstle pozostaje jednym z wiodących naukowców w dziedzinie biomedycyny, publikuje w najbardziej prestiżowych periodykach o zasięgu międzynarodowym.

11 Zob. pkt 15-16 wyroku TS w sprawie C-34/10. Autorowi nie udało się jednak dotrzeć do badań potwierdzających zapewnienia O. Brüstlego. 
z którym uważa się za niemające zdolności patentowej wykorzystywanie embrionów ludzkich do celów przemysłowych lub handlowych.

Pytania sądu krajowego zmierzały do ustalenia następujących kwestii:

1. „Co należy rozumieć pod pojęciem »embrionów ludzkich« zawartym $w$ art. 6 ust. 2 lit. c) dyrektywy [...]?

2. Czy obejmuje ono wszystkie stadia rozwoju życia ludzkiego od zapłodnienia komórki jajowej, czy też muszą być spełnione dodatkowe przesłanki, jak na przykład osiągnięcie określonego stadium rozwoju?

3. Czy obejmuje ono również następujące organizmy: - niezapłodnione ludzkie komórki jajowe, w które wszczepiono jądro komórkowe pochodzące z dojrzałej komórki ludzkiej; - niezapłodnione ludzkie komórki jajowe, które zostały pobudzone do podziału i dalszego rozwoju w drodze partenogenezy?

4. Czy obejmuje ono również komórki macierzyste, które zostały pozyskane z embrionów ludzkich w stadium blastocysty?

5. Co należy rozumieć pod pojęciem »wykorzystywania embrionów ludzkich do celów przemysłowych lub handlowych«? Czy obejmuje ono każde wykorzystanie handlowe w rozumieniu art. 6 ust. 1 dyrektywy, w szczególności również wykorzystanie do celów badań naukowych?

6. Czy wiedza techniczna jest wyłączona $z$ opatentowania na mocy art. 6 ust. 2 lit. c) dyrektywy [...] również wtedy, gdy wykorzystanie embrionów ludzkich nie należy do wiedzy technicznej zastrzeżonej patentem, ale jest niezbędną przesłanką zastosowania tej wiedzy: - ponieważ patent dotyczy wyrobu, którego wytworzenie wymaga uprzedniego zniszczenia embrionów ludzkich, lub - ponieważ patent dotyczy procesu, dla którego wyrób taki jest konieczny jako materiał wyjściowy?"12.

Komentarze doktryny wskazują, iż pytania prejudycjalne zostały sformułowane w sposób sugerujący udzielenie odpowiedzi możliwe odmiennej od wcześniejszego rozstrzygnięcia Rozszerzonej Komisji

12 Zob. pkt 23 wyroku TS w sprawie C-34/10. 
Odwołań Europejskiego Urzędu Patentowego w sprawie WARF/ Thomson ${ }^{13}$. W decyzji Europejskiego Urzędu Patentowego odmówiono nadania kontrowersyjnego patentu, gdyż zasada ochrony godności została rozszerzona również na embriony ludzkie ${ }^{14}$. Rozstrzygnięcie w sprawie WARF/Thomson zostało oparte na przepisach mających na celu implementację do reżimu prawa patentowego dyrektywy o wynalazkach biotechnologicznych. Tym samym RKO dokonała w rzeczonej decyzji pośredniej interpretacji prawa unijnego, w świetle której niedopuszczalne jest opatentowanie wynalazku, który w swym zastosowaniu i produkcji przewiduje świadome i zaplanowane niszczenie embrionów ludzkich ${ }^{15}$. Intencją sądu pytającego w sprawie Brüstle przeciwko Greenpeace było jednak możliwie wąskie zinterpretowanie przez TS wyłączeń zapisanych w dyrektywie, umożliwiające przyjęcie interpretacji przyjaznej dla dalszego rozwoju i wykorzystania wynalazków opartych na wykorzystaniu i zniszczeniu embrionów ${ }^{16}$.

Odpowiadając na pytania prejudycjalne, TS jednak przyjął szeroką definicję embrionu. Uznano, że na potrzeby dyrektywy embrionem ludzkim jest „każda ludzka komórka jajowa począwszy od stadium jej zapłodnienia, każda niezapłodniona ludzka komórka jajowa, w którą wszczepiono jądro komórkowe pochodzące z dojrzałej komórki ludzkiej oraz każda niezapłodniona ludzka komórka jajowa, która została pobudzona do podziału i dalszego rozwoju w drodze partenogenezy; - do sądu krajowego należy ustalenie, w świetle rozwoju nauki, czy komórka macierzysta, która została pozyskana z embrionu ludzkiego w stadium blastocysty, stanowi «embrion ludzki»"17. Wyłączenie ze zdolności patentowej obejmuje zatem wykorzystywanie do celów ba-

13 Decyzja z 25 listopada 2008 r., sygn. akt G 2/06.

14 P. ŁĄCKI, Ludzkie embriony i godność czlowieka $w$ świetle prawa patentowego. Wyrok Trybunatu Sprawiedliwości Unii Europejskiej z dnia 19 października 2011 r. w sprawie Brüstle przeciwko Greenpeace, «Przegląd Sejmowy» 4(111)//2012, s. 36-38.

15 Zob. omówienie decyzji WARF/Thomson w: W. WŁodARCZYK, Zdolność patentowa zastosowań embrionów ludzkich - komentarz do decyzji Europejskiego Urzędu Patentowego w sprawie WARF/Thomson, «Europejski Przegląd Sądowy», 10/2009.

16 Szerzej na ten temat, zob. P. ŁẠCKI, op. cit., s. 37-38.

17 Zob. pkt 38 wyroku TS w sprawie C-34/10. 
dań naukowych, „bowiem przedmiotem patentu może być jedynie wykorzystywanie do celów terapeutycznych lub diagnostycznych, które jest stosowane do embrionu ludzkiego i jest dla niego użyteczne"18. TS uznał również, że, wiedza techniczna jest wyłączona $\mathrm{z}$ opatentowania na mocy dyrektywy, gdy „wymaga uprzedniego zniszczenia embrionów ludzkich lub ich użycia jako materiału wyjściowego, bez względu na stadium, w którym do tego dochodzi, i nawet gdy opis zastrzeżonej wiedzy technicznej nie wspomina o wykorzystywaniu embrionów ludzkich"19.

Przy pierwszej analizie uzasadnienia budzi ono niedosyt i razi wręcz enigmatycznością. Orzeczenie Brüstle przeciwko Greenpeace jest pod tym względem egzemplaryczne dla coraz bardziej znacznej ilości wypowiedzi TS ${ }^{20}$. Co jest może i adekwatne w sprawach gospodarczych, zawodzi jednak przy zetknięciu się z kwestiami filozoficznie i moralnie kontrowersyjnymi. Podstawowym problemem, z którym musiał zmierzyć się TS, był wybór podstawy uzasadnienia swego stanowiska. Przy czym o wskazaniu jasnej podstawy rozważań interpretacyjnych nie świadczy zdanie, iż „Trybunał nie został poproszony o rozważenie kwestii natury medycznej lub etycznej, a więc powinien ograniczyć się do wykładni prawnej właściwych przepisów dyrektywy"21. Nie tyle determinuje ono metodę uzasadnienia, co stanowi jedynie doprecyzowanie przedmiotu wykładni. Rzeczywista podstawa uzasadnienia może nastręczać pewne trudności w prawidłowej identyfikacji. Większa część rozumowania zastosowanego przez TS staje się bardziej zrozumiała dopiero po lekturze opinii rzecznika generalnego ${ }^{22}$. Dopiero

18 Zob. pkt 46 wyroku TS w sprawie C-34/10.

19 Zob. pkt 52 wyroku TS w sprawie C-34/10.

20 Zjawisko to jest określane mianem judicial minimalism, co - oddając jego istotę - można byłoby przetłumaczyć jako „minimalizmu orzeczniczego”.

21 Zob. pkt 30 wyroku TS w sprawie C-34/10.

22 Opinia rzecznika generalnego Yves'a Bota przedstawiona w dniu 10 marca 2011 r. dostępny na stronie: http://curia.europa.eu/juris/document/document.jsf?te$\mathrm{xt}=\&$ docid $=81836 \&$ pageIndex $=0 \&$ doclang $=$ PL\&mode $=1$ st\&dir $=\&$ occ $=$ first\&part $=1$ \&cid=1356975\#Footnote1, dostęp 3 kwietnia.2013 r. 
łączna interpretacja tych dwóch dokumentów pozwala na prawidłowe odtworzenie argumentacji uzasadniającej orzeczenie.

Rzecznik generalny, Yves Bott zasugerował TS oparcie rozważań prawnych na informacjach, które są obiektywne i wynikają z nauki. Ponadto, na potrzeby uzasadnienia własnego stanowiska przyjął, że: „,milczenie nauki lub niemożność wykazania przez nią czegoś również należy uznać za obiektywną informację, na której może opierać się analiza prawna" ${ }^{23}$. Troska o zachowanie tak rozumianej obiektywności była wyrazem obawy, że oparcie interpretacji dyrektywy na podstawach nienaukowych może doprowadzić do odrzucenia stanowiska TS i braku innych niż instytucjonalnie zagwarantowany autorytet podstaw jego uznania. Jednakże, ściśle techniczne sięgniecie do przesłanek empirycznych nie okazało się w przedmiotowej sprawie możliwe. Rzecznik odwoływał się do zasady godności ${ }^{24}$ oraz do wspólnego wszystkim państwom członkowskim minimalnego rozumienia etyki ${ }^{25}$. Trybunał natomiast szukał obiektywizacji swojego uzasadnienia głównie w odwołaniu do brzmienia samej dyrektywy ${ }^{26}$, w tym wyrażonego w niej celu uregulowania ${ }^{27}$ dotychczasowego orzecznictwa własnego ${ }^{28}$, orzecznictwa Rozszerzonej Komisji Odwoławczej Europejskiego Urzędu Patentowego ${ }^{29}$ oraz odwołując się do skuteczności i konsekwencji już przyjętej interpretacji ${ }^{30}$, raz tylko odwołano się do wiedzy ogólnej ${ }^{31}$. O ostrożnej postawie TS świadczy również, że tylko raz dokonano rekonstrukcji celu dyrektywy bez wyraźnego przywołania jej brzmienia ${ }^{32}$. Z powyższego zestawienia wynika, że orzeczenie Brüstle przeciwko Greenpeace zostało uzasadnione w sposób niezwykle formalistyczny i nie można zgodzić

${ }^{23}$ Zob. pkt 47 opinii rzecznika w sprawie C-34/10.

24 Zob. pkt 96 opinii rzecznika w sprawie C-34/10.

25 Zob. pkt 114 opinii rzecznika w sprawie C-34/10.

26 Zob. pkt 29, 30 wyroku TS w sprawie C-34/10.

27 Zob. pkt 27, 32, 33, 34, 42, 44 wyroku TS w sprawie C-34/10.

28 Zob. pkt 25, 27, 29, 30, 31, 33 wyroku TS w sprawie C-34/10.

29 Zob. pkt 45, 51 wyroku TS w sprawie C-34/10.

${ }_{30}$ Zob. pkt 28, 43, 49, 50 wyroku TS w sprawie C-34/10.

31 Zob. pkt 41 wyroku TS w sprawie C-34/10.

32 Zob. pkt 40 wyroku TS w sprawie C-34/10. 
się z zarzutami, aby tak skonstruowana argumentacja nie mogła rościć sobie prawa do nowocześnie rozumianej obiektywności ${ }^{33}$. Nieuchronną konsekwencją przyjętego przez TS modelu rozumowania jest związanie wywiedzionych tą drogą elementów koncepcji godności z brzmieniem konkretnych przepisów dyrektywy o wynalazkach biotechnologicznych. Powyższe związanie może budzić uzasadniony niepokój o tymczasowość stanowiska uzasadnionego w oparciu o sam tekst dyrektywy, który może zostać w perspektywie kilkunastu lat zmieniony. Nalezy jednak wyrazić pogląd, że konstatacje TS dotyczące godności zachowałyby jednak swoją aktualność do rozważań nad interpretacją art. 1 oraz art. 2 Karty praw podstawowych Unii Europejskiej ${ }^{34}$, ponieważ nie tylko rozwijają one normatywne znaczenie zasady godności, ale również dookreślają zakres podmiotowy jej zastosowania ${ }^{35}$.

Zasadnicze znaczenie dla kierunku rozstrzygnięcia miał, związany z ustaleniami nauk medycznych, argument z potencjalności, oparty na przesłance zdolności embrionów do rozwinięcia się w ,,jednostkę ludzką" ${ }^{\prime 3}$. Rozumowanie obecne w dokumentach sprawy Brüstle przeciwko Greenpeace można prześledzić na podstawie następujących punktów: 1) podstawą uzasadnienia powinna być tylko pewna wiedza medyczna, nie jest zatem zadaniem TS rozstrzyganie sporów naukowych ${ }^{37}$; 2) nauka nie jest w stanie wskazać, w którym momencie dokładnie rozpoczyna się życie, co jest determinowane tym, że nie wiadomo, co tak naprawdę rozumieć pod tym filozoficznie i światopoglądowo uwarunkowanym pojęciem. Zadaniem TS nie jest jednak rozstrzyganie sporów światopoglądowych ${ }^{38}$; 3 ) należy zatem poprzestać na wiedzy medycznej stanowiącej, że każdy organizm ludzki powstał w wyniku

33 Zob. zarzuty sformułowane przez S.H.E Harmon, G. Laurie, A. Courtney, Dignity, Plurality and Patentability: the Unfinished story of Brustle v Greenpeace, «European Law Review» 38.1/2013.

34 Karta praw podstawowych Unii Europejskiej, Dz. Urz. UE $2012 \mathrm{Nr} \mathrm{C} \mathrm{83/02.}$

35 Taki wniosek można wysnuć na podstawie: A. WróBel, Art. 1 [w:] Karta Praw Podstawowych Unii Europejskiej. Komentarz, red. A. WróBel, Warszawa 2013.

36 Zob. pkt 34 - 37 wyroku TS w sprawie C-34/10.

37 Zob. pkt 40 opinii rzecznika w sprawie C-34/10.

38 Zob. pkt 81 opinii rzecznika w sprawie C-34/10. 
podziałów pojedynczych komórek, których cechą szczególną jest to, że każda z nich ma zdolność rozwinięcia się w pełni w istotę ludzką ${ }^{39}$; 4) wynika stąd, że już pojedyncze komórki totipotentne posiadają zdolność do dalszego rozwoju, który prowadzi do uformowania się ciała ludzkiego. Zatem, wobec niemożności postawienia jednoznacznie naukowej granicy, w którym momencie rozpoczyna się formowanie ciała ludzkiego, należy przyjąć, iż to te komórki są embrionami w rozumieniu prawa Unii Europejskiej ${ }^{40}$; 5) pozwala to na objęcie zakresem zastosowania zasady godności już pierwszych etapów formowanie się ciała ludzkiego, gdyż dyrektywa „dzięki rozwadze użytych w niej terminów prowadzi nas nie do zdefiniowania życia, lecz ciała ludzkiego. To bowiem «ciału ludzkiemu, w różnych jego stadiach formowania się i rozwoju» dyrektywa ta zapewnia ochronę, zastrzegając wyraźnie, że jest ono wyłączone spod możliwości opatentowania"41. Po uczynieniu powyższych zastrzeżeń, rzecznik Y. Bott objął zakresem zastosowania zasady godności również embrion ludzki, będący pierwszym stadium rozwoju ciała ludzkiego: „Z dyrektywy wynika tym samym, że ochrona godności człowieka stanowi zasadę, która ma zastosowanie nie tylko do istniejącej osoby ludzkiej, czyli narodzonego dziecka, lecz również ciała ludzkiego od pierwszego stadium jego rozwoju, to znaczy od stadium zapłodnienia"42.

Częstokroć podnosi się, iż w toku zaprezentowanego stanowiska byłoby możliwe przyjęcie optyki nakazującej szersze uwzględnienie najnowszych badań z zakresu biomedycyny. Wówczas jednak zakres zasady prawnej wywiedzionej przez TS z dyrektywy mógłby wzbudzić wątpliwości przy pierwszym pojawieniu się badań modyfikujących dotychczasowy stan wiedzy empirycznej. Ponadto, nie jest zadaniem

39 Zob. pkt 84 opinii rzecznika w sprawie C-34/10.

40 Zob. pkt 85 opinii rzecznika w sprawie C-34/10.

41 Zob. pkt 72 opinii rzecznika w sprawie C-34/10.

42 Zob. pkt 95 opinii rzecznika w sprawie C-34/10. Pomimo tego, ze sam TS uniknął definiowania ,życia ludzkiego”, to można zadać sobie pytanie, czy możliwe jest istnienie rozwijającego się i podtrzymującego swoje funkcje życiowe ciała ludzkiego bez życia ludzkiego, zob. zdanie rzecznika: „Ciało istnieje, formułuje się i rozwija niezależnie od tego, co w nim żyje" (pkt 73 opinii rzecznika w sprawie C-34/10). 
TS interpretacja najnowszych wyników badań, tylko interpretacja prawa, a ta została w opinii rzecznika oparta na zasadzie godności. Prowadzi to do wniosku, że argument medyczny nie stanowił rzeczywistej i samoistnej podstawy rozstrzygnięcia. Przesłanka potecjalności była jedynie służebna wobec prawnej zasady godności.

Godność ludzka jest wskazana jako podstawa prawa UE w preambule $^{43}$ oraz $\mathrm{w}$ art. 1 Karty praw podstawowych Unii Europejskiej ${ }^{44}$ stanowiącym, że „Godność człowieka jest nienaruszalna. Musi być szanowana i chroniona". Znalazła również swój normatywny wyraz w motywie 16 dyrektywy, nakazującym stosowanie prawa patentowego z uwzględnieniem podstaw zasad chroniących godność i integralność osoby ludzkiej. Nie zostało jednak jeszcze w pełni rozwinięte, jak należy rozumieć zakres tej zasady na płaszczyźnie prawa $\mathrm{UE}^{45}$, być może dlatego, że nie sposób tutaj uciec od rozstrzygnięć aksjologicznych. Stwierdzenie, że thumaczenie zasady godności poprzez pryzmat tradycji, z której się ona wywodzi, jest „bezowocne i bezcelowe”, w zamian za to poszukiwanie jej źródeł w sprzecznych ze sobą kierunkach myślowych jest nacechowane określoną ideologią prowadząca do postawy etycznego sceptycyzmu i zdającą się na orzecznictwo jako jedyny wyznacznik znaczenia normatywnej zasady godności obecnej w unijnych aktach prawnych ${ }^{46}$. O tym, że dotychczasowe orzecznictwo nie może być jedynym źródłem interpretacji zasady godności, świadczy nieliczna ilość wypowiedzi TS w tej materii. W sprawie Omega Spielhallen TS ograniczył się jedynie do stwierdzenia, że „cel w postaci ochrony godności ludzkiej jest zgodny z prawem wspólnotowym, niezależnie od tego, że w Niemczech zasada poszanowania godności ludzkiej korzysta ze szczególnego statusu jako niezależne prawo podstawowe” oraz że „Tak Wspólnota, jak i Państwa Członkowskie mają obowiązek przestrzegania praw podstawowych, więc ochrona tych

43 „... Unia jest zbudowana na niepodzielnych, powszechnych wartościach godności osoby ludzkiej, wolności, równości i solidarności ...”

44 Karta praw podstawowych Unii Europejskiej, Dz. Urz. UE $2012 \mathrm{Nr}$ C 83/02.

45 Szerzej na ten temat zob. L. BoseK, Gwarancje godności ludzkiej i ich wptyw na polskie prawo cywilne, Warszawa 2012, s. 207-255 i 355-361.

46 Por. A. Wróbel, op. cit., s. 36 i n. 
praw stanowi co do zasady wystarczające uzasadnienie ograniczenia zobowiązań nałożonych przez prawo wspólnotowe" ${ }^{47}$. Niechęć TS do bezpośredniego rozwijania normatywnego znaczenia zasady godności na płaszczyźnie prawa UE może wynikać z kilku przyczyn. Po pierwsze, kwestie związane $\mathrm{z}$ ochroną praw podstawowych nadal pozostają niewielkim ułamkiem całości orzecznictwa. Po drugie, normatywna treść zasady godności należy do europejskiej wspólnoty prawnej, stąd też nie ma potrzeby szczegółowego rozwijania jej znaczenia. Po trzecie, koncepcja godności, tak jak każda inna zasada prawna, może być w ujęciu TS dynamiczna i zależy od jej kontekstowego zastosowania, czego wyrazem jest również fakt, iż pojawia się ona w orzeczeniach stanowiących odpowiedzi na pytania prejudycjalne skierowane w związku z zindywidualizowanym stanem faktycznym i prawnym. Jej dynamizm wyraża się w tym, że wiele zależy choćby od sposobu sformułowania pytań prejudycjalnych przez sąd pytający, czy od okoliczności określonej sprawy.

Brak szerszego rozwinięcia zasady godności może również wynikać z podnoszonych przez niektórych wątpliwości co do jej niejednoznacznego statusu teoretyczno-prawnego ${ }^{48}$. Z ustaleń poczynionych przez Roberta Alexy’ego można wywieść wniosek, że normy wyrażające godność są zarówno zasadami, jak i regułami, wśród których zasada godności ma pierwszeństwo przed zasadami przeciwstawnymi ${ }^{49}$. Zgodnie z częścią zastrzeżeń wysuwanych w doktrynie można zadać pytanie, czy Trybunał powinien był dokonać ważenia zasady godności np. z prawem do opieki medycznej bądź z wolnością badań naukowych. W tym przypadku odpowiedź musi być przecząca, bowiem norma-reguła oparta na godności, statuowana przez art. 6 ust. 2 lit c dyrektywy

47 Wyrok z dnia 14 października 2004 r. C-36/02 Omega Spielhallen- und Automatenaufstellungs-GmbH przeciwko Oberbürgermeisterin der Bundesstadt Bonn Zb. Orz. 2004 I-09609, pkt 34 - 35.

48 Przyjmuję tutaj teorię Roberta Alexy'ego do opisu prawa unijnego, zob. odmienny pogląd: C. HiLson, Rights and Principles In EU Law: A Distinction Without Foundation?, «Maastricht Journal of European \& Comparative Law» 193/2008.

49 R. Alexy, Teoria praw podstawowych, tłum. B. KwiatKowsKa, J. ZaJadŁo, Warszawa 2010, s. 93. 
UE o wynalazkach biotechnologicznych w związku z jej motywem 16, ma bezwzględne pierwszeństwo zastosowania przed innymi regułami. Z drugiej strony, należałoby jednak oczekiwać jasnego wyartykułowania powyższych konsekwencji zasady godności, gdyż sama przez się nie posiada ona statusu zasady absolutnej ${ }^{50}$. Niemniej w podniesienie rangi zasady godności i jej dookreślenie w Karcie praw podstawowych Unii Europejskiej jako „nienaruszalnej” skłania ku przyznaniu takiego właśnie statusu na płaszczyźnie prawa Unii Europejskiej.

Wypada w tym miejscu poczynić jeszcze jedną uwagę. Częstokroć podnoszonym argumentem przeciwko zasadności rozstrzygnięcia zawartego w orzeczeniu Brüstle przeciwko Greenpeace jest brak konsensusu w przestrzeni prawnej państw członkowskich co do identyfikacji zagadnienia embrionów i badań na komórkach macierzystych ${ }^{51}$. Nie wydaje się jednak, żeby to właśnie konsens w kwestii dopuszczalności badań z użyciem embrionów ludzkich miał być najlepszym miernikiem słuszności decyzji podjętej w przedmiotowej sprawie. Świadomość nieprzystawalności dotychczasowych, opartych na rachunku strat i korzyści, metod dyskursu w kwestiach bioetycznych skłania niektórych do zaakceptowania konstruktywnej roli emocji i wartości jako nieodłącznego elementu debaty wokół zdolności patentowej wynalazków uzyskanych z wykorzystaniem embrionów ludzkich ${ }^{52}$. Tym też należy tłumaczyć pojawienie się w opinii rzecznika porównania mogącego wywoływać emocjonalne reakcje audytorium, którego celem było odrzucenie argumentu, jakoby sposób pobierania komórek macierzystych był bez znaczenia, gdyż przedmiotem wniosku patentowego jest sam wynalazek, a nie sposób pozyskania niezbędnych do jego wytworzenia ,półproduktów”. Rzecznik Y. Bott poczynił następującą uwagę: „Rzeczywistość prawna wynikająca z działalności Międzynarodowego Trybunału Karnego dla byłej Jugosławii pokazuje, $[\ldots]$ że w trakcie wydarzeń w tym państwie więźniowie byli mordowani w celu pobrania od nich organów, które stanowiły

50 R. Alexy, op. cit., s. 95.

51 P. ŁĄCKI, op. cit., s. 53 i n.

52 K. Sideri, op. cit., s. 824. 
przedmiot nielegalnego handlu. Czy gdyby nie chodziło o nielegalny handel, lecz eksperymenty będące źródłem „wynalazków” w znaczeniu, jakie pojęcie to posiada w prawie patentowym, przysługiwałaby im zdolność patentowa ze względu na to, że sposób ich pozyskania wykraczałby poza zastrzeżenie techniczne patentu?"53. W odpowiedzi na te słowa zaczęto konstruować różne inne porównania. K. Sideri opisuje sytuację, wedle której, gdyby wybuchł pożar w laboratorium, gdzie przechowywane są embriony oraz w którym przebywa pięcioletnie dziecko, w pierwszej kolejności ratowalibyśmy dziecko, a nie zapłodnione komórki macierzyste ${ }^{54}$, w związku z czym nie sposób stawiać znaku równości między godnością ludzi przed momentem urodzin i po nim. Zastanowić jednak może absurdalność opisywanej przez K. Sideri „sytuacji”. Ciężko sobie wyobrazić specjalistyczne laboratorium medyczne pełniące jednocześnie funkcję przedszkola i biegające wśród białych ścian kilkuletnie dzieci. Nie odwołując się do tak skrajnych emocji, inny autor, E. Bonadio, zauważa, ze gdyby chcieć konsekwentnie zastosować logikę rozumowania rzecznika generalnego wyrażoną w dyskutowanym porównaniu, należałoby zadać sobie pytanie, czy produkty wyprodukowane w państwach trzeciego świata dzięki niewolniczej pracy dzieci nie powinny również zostać pozbawione zdolności patentowej ${ }^{55}$. Tutaj należy wskazać, że sam produkt nie został opatentowany, gdyż został wykonany przez niewolniczą pracę dzieci. Wybór rynku pracy, na którym jest on wytwarzany, należy do producenta. Tymczasem technologia opracowana przez O. Brüstlego nie pozostawia żadnego wyboru etycznego - warunkiem jej zastosowania jest komercyjne wykorzystanie i zniszczenie integralności istoty ludzkiej. W jeszcze innym komentarzu niepełnosprawny autor zarzuca, że opinia rzecznika generalnego pozbawia szans na wyleczenie z choroby, na którą cierpi dziennikarz. Zaznaczając przy tym, że nie rozumie, dlaczego godność embrionów miałaby być równie wysoko chroniona, co jego własna - skoro żyje w społeczeństwie, w któ-

53 Zob. pkt 106 opinii rzecznika w sprawie C-34/10.

54 K. Sideri, op. cit., s. 828.

55 E. Bonadio, op. cit., s. 442. 
rym „zezwala się na aborcję jako prawnie i etycznie dopuszczalną" 56 . Pytanie tylko, czy rzeczywiście zastosowanie embrionalnych komórek macierzystych daje całkowitą pewność wyleczenia wszystkich chorób. Podane przykłady wskazują, że odwołania do emocji niekoniecznie mogą służyć uzasadnieniu stanowiska zgodnego z orzeczeniem TS. Tym bardziej, że merytoryczna wartość argumentów, opartych jedynie na wymienionych przez krytyków rozstrzygnięcia TS przykładach, wydaje się wątpliwa. Siła przekonywania wyrażona przez krytyków opinii rzecznika generalnego jest zależna od szerszej wizji wartości, którymi powinny się kierować społeczeństwa państw członkowskich UE. Jedno orzeczenie Trybunału nie jest w stanie zmienić całości postmodernistycznej narracji, wskazuje jednak, że, przyjmując narzucone przez nią reguły prowadzenia dyskursu, można uzasadnić stanowisko szanujące integralność osoby ludzkiej.

Przyjmując reguły liberalnego dyskursu, rzecznik generalny zaznaczył, że postęp wiedzy technicznej może doprowadzić do zmiany stanowiska $\mathrm{TS}^{57}$, co należy tłumaczyć jako ucieczkę od jednoznacznego rozstrzygnięcia filozoficznego statusu pojęcia godności obecnego w aktach prawa $U^{58}$. Jednakże, brak etycznego zakorzenienia unijnego rozumienia zasady godności prowadzi nie tylko do nie przewidywalności dalszej ewolucji zastosowania tej koncepcji, ale bezpośrednio rzutuje na system regulacji Unii Europejskiej w dziedzinie biotechnologii oraz finansowania etycznie kontrowersyjnych badań naukowych. Zwłaszcza, że powszechnym wydaje się oczeki-

56 A. PALmer, Should the European Court be allowed to dash my hopes of a cure?, «The Telegraph», data publikacji on-line: 30 kwietnia 2011, dostęp 24 lipca 2013 r., źródło: http://www.telegraph.co.uk/comment/columnists/alasdair-palmer/8485520/ Should-the-European-Court-be-allowed-to-dash-my-hopes-of-a-cure.html

57 Zob. pkt 48 opinii rzecznika w sprawie C-34/10.

58 Należy zaznaczyć, że na takie wyjaśnienie pozwolił sobie działający również w warunkach pluralistycznego i zróżnicowanego społeczeństwa Federalny Trybunał Konstytucyjny, stwierdzając, że podstawą normy godności człowieka jest: „wyobrażenie człowieka jako istoty duchowo-moralnej, dążącej do samookreślenia i rozwoju w warunkach wolności. Wolność tę ustawa zasadnicza pojmuje nie jako wolność jednostki wyizolowanej i autokratycznej, lecz jako jednostki osadzonej we wspólnocie i związanej z nią." Zob. R. Alexy, op. cit., s. 270. 
wanie dotyczące relacyjnego odczytanie godności w kontekście praw społeczeństwa do lepszej wiedzy i opieki medycznej ${ }^{59}$. Odrzucenie związku między godnością a fazami życia ludzkiego, poprzedzającymi narodziny, jest argumentem na rzecz możliwie wąskiego odczytania reguły wywiedzionej z orzeczenia Brüstle przeciwko Greenpeace i prowadzi część autorów do wniosku, że dozwolone są badania naukowe z użyciem i zniszczeniem embrionów ludzkich, tyle tylko, że ich wyników nie można objąć ochroną patentową ${ }^{60}$. Instrumentalizacja ciała ludzkiego - i w rozumieniu Trybunału - również embrionów ludzkich prowadzi wprost do praktyk eugenicznych ${ }^{61}$, tym bardziej niepokojących, że ukazywanych w przeważającej mierze jako pozytywne osiągnięcie naszej cywilizacji. Polegać ma ono m.in. na realnej perspektywie świadomego decydowania przez rodziców o niektórych cechach swoich dzieci jako wyzwoleniu od przypadku na rzecz wyboru przyszłości następnych pokoleń ${ }^{62}$. Zjawisko to jest opisywane przez Jürgena Habermasa jako „eugenika liberalna” pozwalająca na uczynienie potencjalnej jakości przyszłego życia podstawowym kryterium jego istnienia ${ }^{63}$.

Krytyka praktycznych konsekwencji orzeczenia wykraczałaby poza ramy niniejszego opracowania. Warto jedynie zasygnalizować, że orzeczenie TS może budzić wątpliwości dotyczące naruszenia zobowiązań wynikających z art. 27 Porozumienia w sprawie handlowych aspektów praw własności intelektualnej ${ }^{64}$. Jak do tej pory, brakuje

59 K. SidERI, op. cit., s. 829.

60 S.H.E Harmon, G. Laurie, A. Courtney, op. cit., s. 101 i n.

${ }^{61}$ K. Sideri, op. cit., s. 825 i n.

62 A. Krajewska, Conceptual Quandaries about Genetic Data - A Comparative Perspective, «European Journal of Health Law»16 /2009, s. 19.

${ }^{63}$ Zob. J. Habermas, Przyszłość natury ludzkiej. czy zmierzamy eugenetyki liberalnej, przeł. M. Łukasziewicz, Warszawa 2003, s. 75-81; P. Blus, Godność i idea godności a roszczenia nauki [w:] Badania nad embrionami ludzkimi $w$ świetle etyki i prawa, red. E. Podrez, T. StAwecki, Warszawa 2013.

64 DZ. Urz. WE 1994 Nr L 336/214. Sprzeczność orzeczenia TS w sprawie C-34/10 z tym uregulowaniem podkreśla S. Williams, Brüstle v. Greenpeace: The Court of Justice of the European Union Interprets the Term ,Human Embryo” Widely, Restricting Member States' Discretion To Pass National Patent Legislation for Bio- 
również danych empirycznych pozwalających zweryfikować domysły niektórych autorów, związane m.in. z emigracją potencjału naukowo-badawczego do państw, w których wynalazki oparte na embrionach ludzkie uzyskały już zdolność patentową ${ }^{65}$. Celem niniejszego opracowania jest analiza omawianego orzeczenia uwzględniająca argumentacyjny aspekt jego uzasadnienia. W opinii piszącego te słowa, wyrok w sprawie Brüstle przeciwko Greenpeace stanowi istotny przyczynek do szerszej dyskusji na temat uzasadnienia praw podstawowych i ich dynamicznej interpretacji. Wypowiedź TS, wyostrzając jeszcze bardziej dylemat wyboru między zasadami autonomiczności a skuteczności w systemie prawnym Unii Europejskiej ${ }^{66}$, powinna być, ponadto, istotnym przyczynkiem do prac legislacyjnych nad jednolitym patentem europejskim.

Brak jednoznacznie wyartykułowanego filozoficznego i etycznego zakorzenienia zasady godności prowadzi do nieprzewidywalności dalszej ewolucji zastosowania koncepcji praw podstawowych. Zaobserwować przy tym można dwie tendencje, pierwszą jest odrzucenie związku między godnością a wszystkimi fazami życia ludzkiego, drugą natomiast relacyjne odczytanie zasady godności. Orzeczenie Brüstle przeciwko Greenpeace nie przesądziło w sposób nieodwołalny kwestii granic rozwoju biomedycyny i zakresu odpuszczalnej ingerencji nauki w życie ludzkie. Warto jednak wyartykułować kilka jego nie tylko prawnych konsekwencji. Po raz pierwszy przedstawiono szerszej opinii

technological Inventions, «Tulane Journal of International and Comparative Law» 20.2/2012, s. 573.

65 Przyznają to również krytycy rozstrzygnięcia przyjętego przez TS, zob. S.H.E Harmon, G. Laurie, A. Courtney, op.cit., s. 100.

66 Przyjmuję tutaj, że system prawny Unii Europejskiej można opisać za pomocą równoważności i napięcia między jego wewnętrznymi trzema zasadami: autonomicznością rozumianą jako ograniczenie zakresy regulacji prawa UE, zasadą powierzenie kompetencji wewnątrzpaństwowych oraz zasadą skuteczności, rozumianą jako obowiązek zapewnienie pełnego i możliwie jednolitego stosowania prawa UE w dziedzinach nim objętych, zob. D. SARMiEnto, Dealing with Judicial Minimalism at the European Court of Justice, [w:] Constitutional Conversations in Europe - Actors, Topics and Procedures, eds. Monica Claes, Maartje de Visser, Patricia Popelier and Catherine Van de Heyning, Cambridge-Antwerp-Portland, s. 16-18. 
publicznej zagadnienie granic rozwoju biomedycyny. Na płaszczyźnie nie tylko dyrektywy, ale też pośrednio Karty praw podstawowych Unii Europejskiej postawiono też istotną barierę dla dalszego rozwoju komercyjnego wykorzystania badań nad macierzystymi komórkami embrionalnymi, uznając ich potencjał do stania się istotą ludzką za wystarczającą przeszkodę na drodze do ich przemysłowego zniszczenia. Wyeliminowano tym samym koncepcje godności pozwalające na instrumentalne traktowanie integralności osoby ludzkiej. Niemniej, aktualnym pozostaje zadanie poczynienia jasnych dystynkcji i dokonania wyborów etycznych stojące bezustannie przed sędziami i legislatorami, poruszającymi się na płaszczyźnie już nie tylko krajowych konstytucji, ale też ponadnarodowego prawa Unii Europejskiej. Dylemat, który powstaje w związku z rozwojem współczesnej nauki, sprowadza się do wyboru pomiędzy integralnym rozumieniem życia człowieka, obejmującym wszystkie fazy jego rozwoju, a koncepcją jednostki ludzkiej jako produktu możliwości technicznych.

\section{Human Dignity in the Judgment in Case C-34/10 Oliver Brüstle $\checkmark$ GREENPEACE EV}

\section{Summary}

The judgment in Case C-34/10 Oliver Brüstle v Greenpeace eV. has not defined limits to the development of biomedicine, nor has it demarcated a boundary to science's admissible intervention in a human life. However, a few of its consequences, not only the legal ones, call for special emphasis. First of all, it was the first time that the question of boundaries to progress in biomedicine was put to European public opinion. Embryonic stem cells were recognised as having the potential to develop into a human being, which gives sufficient grounds for a prohibition on their commercial destruction; thereby an effective barrier was laid down to further development in the commercial application of embryonic stem cell research, on the grounds not only of secondary law (directives), but also of the EU Charter of Fundamental 
Rights. The C-34/10 judgment has thus ruled out all concepts of dignity which adopt an instrumental approach to the integrality (inviolability) of the human person. However, the task of making ethical and valueoriented distinctions is still a problem facing judges and legislators in their everyday legal practice, since they now have to abide not only by the provisions of their respective national constitutions, but also by the supranational EU law. The dilemma which has emerged in connection with progress in contemporary science has put the European Union in a situation where it has to make a choice between the integral concept of human life covering all the stages of human development, and the notion of the human individual as the outcome of technological potential. 